\section{Efficacy of Clinical Prognostic Factors on Survival in Patients with Glioblastoma}

\section{Glioblastomali Hastalarda, Klinik Parametrelerin Yașam Süresi Üzerine Etkileri}

\begin{abstract}
AIM: Glioblastoma is the most common and highest-grade infiltrative astrocytoma. It is usually associated with a bad prognosis. Histological grading is highly predictive of an aggressive behavior, with a mean survival rate of 1 year. Nonetheless, individual patient survival can vary substantially, ranging from 1 month to over 5 years. Several distinct clinical parameters and molecular alterations have recently been described in glioblastoma. The present study compares clinical, radiologic and therapeutic parameters in a series of glioblastomas to identify prognostic factors.

MATERIAL and METHODS: We evaluated 50 cases who were operated on for intracranial glioblastoma between January 1998-March 2004 retrospectively. All clinical records, radiological records and management modalities were evaluated as prognostic value.

RESULTS: The mean survival time was 7.5 months (range, 1-18 months). We confirmed the patients' age, gender, Karnofsky Performance Scale score at discharge, postoperative radiotherapy and reoperation as decisive prognostic factors after multivariate analyses.

CONCLUSION: We could show that some clinical parameters and treatment modalities were associated with prognosis. Younger age, male gender, higher Karnofsky Performance Score at discharge, total surgical resection, radiotherapy and reoperation were predictor for better prognosis.
\end{abstract}

KEYWORDS: Glioblastoma, Survival time, Prognosis

\section{ÖZ}

AMAÇ: Glioblastoma, astrositomalar içinde hem en yüksek evreli infiltrasyon gösteren hem de en sık saptanan tümördür. Histolojik evreleme, ortalama 1 yıllık yaşam süresi ile birlikte olan agresif davranışı yüksek oranda gösterebilmektedir. Bununla beraber, 1 aydan 5 yıla aşan sürelere kadar farklı yaşam sürelerine sahip hastalar mevcuttur. Prognozu tahmin edebilmek için glioblastomalı hastalarda farklı klinik parametreler ve moleküler değişiklikler tanımlanmıştır. Bu çalışmada, klinik, radyolojik parametreler, tedavi modaliteleri, prognostic değerler olarak araştırılmışlardır.

YÖNTEM ve GEREÇ: Ocak 1998-Mart 2004 tarihleri arasında kliniğimizde opere edilerek Glioblastoma tanısı alan 50 hasta değerlendirmeye alındı.Tüm klinik kayıtlar, radyolojik incelemeler, ve tedavi modaliteleri prognoz göstergeleri olarak değerlendirildi.

BULGULAR: Ortalama yaşam süresi 7,5 aydı (1-18 ay). Çalışmamızda hastanın yaşı, cinsi, Hastaneden çıkış sırasındaki Karnofsky Performans Skoru, cerrahi rezeksiyon miktarı, Operasyon sonrası radyoterapi uygulanımı, tekrarlayan cerrahi uygulanmış olması, multivariate analizler sonrası da prognoz üzerine etkili faktörler olarak tespit edildi.

SONUÇ: Bazı klinik parametrelerin ve tedavi modalitelerinin prognoz üzerine bağımsız olarak etki ettiğini tespit ettik. Genç yaş, erkek cinsiyet, Hastaneden çıkış sırasındaki Karnofsky Performans Skoru'nun 70'in üzerinde oluşu, total cerrahi rezeksiyon uygulanmış olması, cerrahi sonrası radyoterapi uygulanmış olması ve tekrarlayan cerrahi uygulanmasının bağımsız olarak yaşam süresini uzattığı olarak gösterildi.

ANAHTAR SÖZCÜKLER: Glioblastoma, Yaşam süresi, Prognoz

\section{Bekir TUGCU \\ Lutfi Sinasi POSTALCI \\ Omur GUNALDI \\ Osman TANRIVERDI \\ Hidayet AKDEMIR}

Bakırköy Research and Training Hospital for Neurology, Neurosurgery and Psychiatry, 2nd Neurosurgery Clinic, İstanbul, Turkey

Received : 31.07.2009

Accepted : 04.12.2009

This manuscript was partially presented in the $20^{\text {th }}$ Turkish National Neurosurgeon Congress. 28.04.2006/02.05.2006 Belek, Antalya/Turkey

Correspondence address:

Bekir TUGCU

Phone : +90 2125438667

E-mail : bekirtugcu@superonline.com 


\section{INTRODUCTION}

Glial tumors are the most common type of primary brain neoplasm and constitute approximately $60 \%$ of all primary brain tumors. In glioblastoma patients survival time is still approximately 1 year despite all treatment modalities including surgical resection, radiation therapy and chemotherapy $(6,16,20,25,26,34,35)$. Nevertheless, survival beyond the fifth year after surgery is observed in a small number of patients. For this reason, there has been longstanding interest in the identification of prognostic markers for glioblastoma.

A number of methods for predicting the outcome in glioblastoma patients have been described. Age, Karnofsky performance scale, tumor localization, tumor size, histopathologic subgroups, extent of resection, radiotherapy and reoperation, molecular and genetic factors like Annexin 7 expression, MIB labeling index and p 53 expression have been evaluated for predicting prognosis $(1,3,4,7-12,15,18$ 20,29,30,32). Cell mitotic activity and proliferation indicators may give more information about aggressive behavior of tumors than clinical parameters. The determination of the MIB I antibody against Ki67, which is a nuclear antigen may demonstrate the biologic behavior of glioblastoma. Most studies that evaluate prognostic value have conflicting results.

In this study, we aimed to evaluate the efficacy of clinical, radiological and surgical prognostic parameters on the length of survival in 50 patients with glioblastoma.

\section{MATERIAL and METHODS}

We evaluated all patients who were operated on for intracranial glial tumors at the Bakırkoy Research and Training Hospital for Neurology, Neurosurgery and Psychiatry, 2nd Neurosurgery Clinic, between January 1998-March 2004 retrospectively. 68 of the 84 patients were graded as 4 according to the WHO grading system. Only 50 patients who had medical and follow-up records were included in the study.

All of the clinical and radiological records from the 50 cases were reviewed retrospectively. Age, gender, duration of complaint, Karnofsky Performance Score at the time of admission and on discharge were recorded. Time of duration of complaint was classified as $0-1$ month, 1-2 months,
2-6 months, 6-12 months and 12-24 months. A values of 70 was preferred for a cut-off value for the Karnofsky Score, because of 70 is the limit value for an independent life. Radiological data was reevaluated and widest diameters of tumors, cyst, edema, shift from midline and contrast enhancement were recorded for each patient.

Management modalities were classified as: Stereotactic biopsy; stereotactic biopsy plus radiotherapy; surgical resection; surgical resection plus radiotherapy. Early postoperative CT was obtained to evaluate the amount of resection for all patients. Early postoperative MR imaging's is not routine in our institute and was performed in 22 (44\%) patients. Amount of resection was defined as; total resection (there is not any residual tumor tissue on the CT and/or MR image), subtotal resection (residual tumor tissue is less than $10 \%$ percent of the initial tumor), partial resection (residual tumor tissue is greater than $10 \%$ percent of the initial tumor). Glasgow outcome scale and Karnofsky performance scale were used to evaluate patient's functional status at discharge for all patients.

All of the patients were reevaluated by telephone method. All information about their last neurological status was collected from them or their relatives. The date of death or last examination of the patient was used to establish endpoints.

Statistical analyses were calculated with SPSS for windows (SPSS for Windows; version 10.0; SPSS, Inc., Chicago, IL). Kaplan Meier method was used for the calculation of median survival time. The effects of variables on the survival time were evaluated by Log Rank test. Stepped Cox regression test was used for the multivariate analyses. Anova test was used for numeric variables and Pearson ${ }^{-2}$ test was used for nominal and ordinal variables. Variables were determined as; 1) age, 2) gender, 3) Karnofsky performance scoring at the time of diagnosis and the early postoperative period, 4) extension of resection, 5) localization, 6) radiological findings, 7) therapy modalities, 8) reoperation. $\mathrm{P}$ value under 0.05 was determined as significant for all statistics.

\section{RESULTS}

The postoperative follow-up period was in range from 5 to 65 months. Forty patients died within the follow-up period. The mean survival time was 7.5 
months (range, 1-18 months). The efficacies of prognostic variables upon survival were summarized in Table I and Table II.

Age and Gender: The patients included 22 females $(44 \%)$ and 28 males (56\%), ranging in age from 9 to 79 years with a mean of $54.12( \pm 15.18)$ years. The ages of female patients ranged from 9 to 74 years (mean age, 51.52 years), and male patients ranged from 32 to 79 years (mean age, 56.15 years). Survival time for males (8.93 months) was significantly longer than females (5.67 months) in univariate analysis $(\mathrm{p}=0.01)$ (Figure 1$)$.

Age was used as numerical data and we did not use any cut off value. Increasing age was a significant variable for worse prognosis. Younger patient's survival time is longer than elder $(p=0.05)$.

Duration of complaint: The time from the first complaint to hospital admission was less than 2 months in over half of patients and only shorter than 8 months for $90 \%$ of patients.

The signs of increased intracranial pressure were a prominent complaint for admission. One third of patients had been admitted to the hospital with only a headache and/or vomiting. Only $25 \%$ of the patients had additional neurological deficits. Neither clinical symptoms nor duration of complaint influenced the survival time in the present study.

Karnofsky Performance Score: According to Karnofsky Performance scale, $19(38 \%)$ of the 50 patients had dependency as below cut off value.

Karnofsky Performance Scale at admission did not show a significant influence on survival time ( $\mathrm{p}=0.41$ ) according to Log Rank test and Multiple Cox regression analysis.

At discharge from the hospital evaluation, 40 patients $(80 \%)$ were in or above 70 and independent, 10 patients $(20 \%)$ were under 70 according to Karnofsky Performance Scale.

Survival time for patients whom were dependent on discharge according to Karnofsky Performance scale was $4.56 \mathrm{~m}$. and $8.18 \mathrm{~m}$ for independent patients. A significant difference was found between the two groups according to Log-Rank test $(p=0.005)$ (Figure 2). Karnofsky Performance Score on discharge seemed to be an important independent factor on survival time according to multivariate analysis.

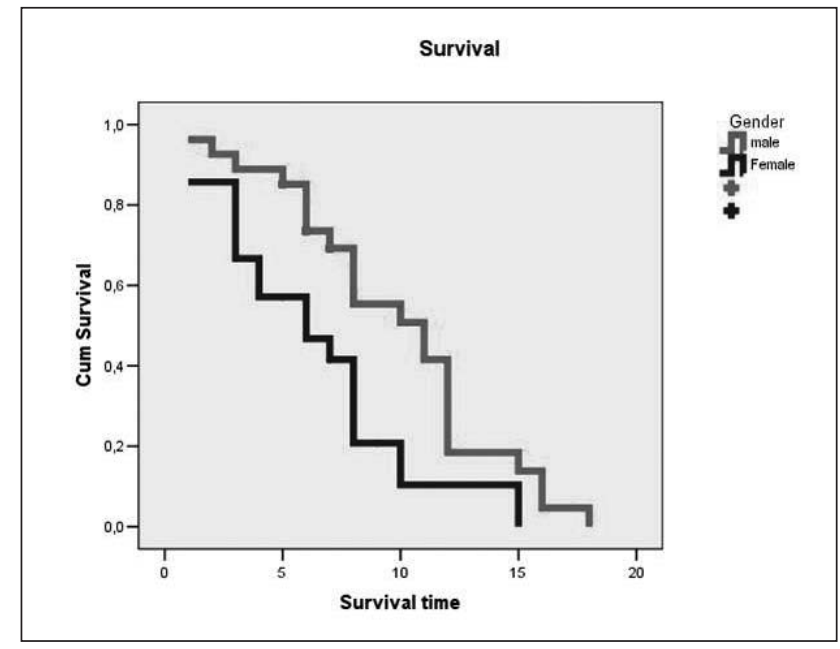

Figure 1: Overall survival curve according to gender.

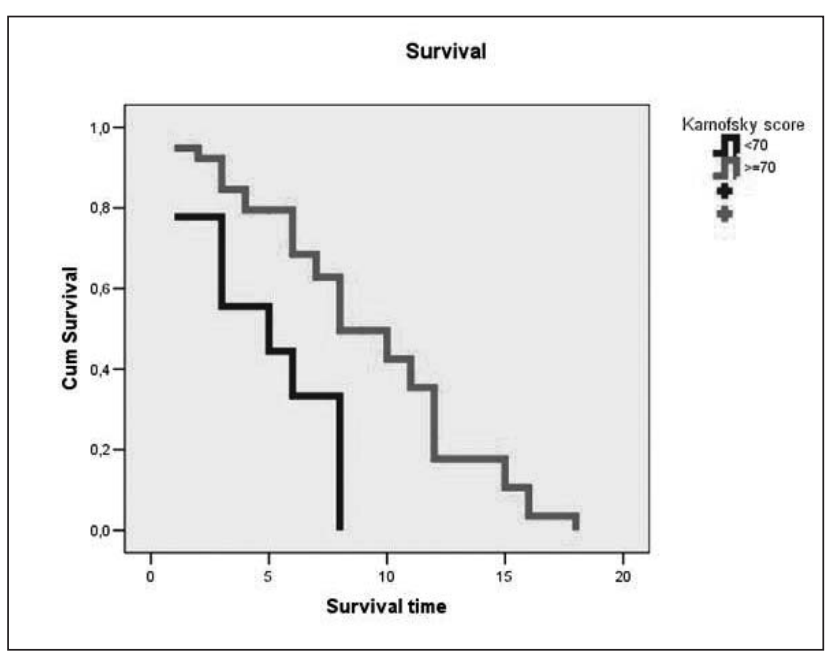

Figure 2: Overall survival curve according to Karnofsky Performance Score at discharge.

Radiologic characteristics: Table III shows radiological characteristics of the tumor (localization, tumor size, midline shift, contrast enhancement, presence of peritumoral edema, cystic component).

Survival time was not affected by tumor localization, existence of cyst, midline shift, enhancement of contrast and tumor volume according to both univariate and multivariate analysis.

Extent of resection: Survival time for patients who underwent only stereotactic biopsy was 3.6 months and was statistically significantly shorter than those underwent surgical resection at any degree (7.95 months). 
Table I: Efficacies of Prognostic Variables on Survival Time after Univariate and Multivariate Analysis.

\begin{tabular}{|c|c|c|c|c|}
\hline & Median survival time & $\begin{array}{c}\text { univariate analysis } \\
\text { p-value }\end{array}$ & \multicolumn{2}{|c|}{$\begin{array}{c}\text { multivariate analysis } \\
\text { p-value }\end{array}$} \\
\hline $\begin{array}{l}\text { female } \\
\text { male }\end{array}$ & $\begin{array}{l}5.67( \pm 3.45) \\
8.93( \pm 4.41)\end{array}$ & $0.01^{*}$ & $0.05^{*}$ & $(1-4.46)$ \\
\hline Age & & $0.05^{*}$ & $0.05^{*}$ & $(1-1.05)$ \\
\hline Time of suffering & & 0.27 & & \\
\hline $\begin{array}{l}\text { Karnofsky score (admission) } \\
\quad<70 \\
>70\end{array}$ & $\begin{array}{l}6.89( \pm 4.96) \\
7.87( \pm 3.90)\end{array}$ & 0.41 & 0.17 & $(0.69-7.73)$ \\
\hline $\begin{array}{l}\text { Localization } \\
\text { eloquent } \\
\text { noneloquent }\end{array}$ & $\begin{array}{l}7.42( \pm 5.11) \\
7.55( \pm 3.78)\end{array}$ & 0.37 & & \\
\hline $\begin{array}{cc}\text { Radiological characteristic } \\
\text { cyst } & \text { yes } \\
& \text { no }\end{array}$ & $\begin{array}{l}7.92( \pm 5.41) \\
7.34( \pm 3.90)\end{array}$ & 0.64 & & \\
\hline $\begin{array}{ll}\text { midline shift } & \text { yes } \\
\text { no }\end{array}$ & $\begin{array}{l}8.03( \pm 4.39) \\
6.33( \pm 3.99)\end{array}$ & 0.12 & & \\
\hline $\begin{array}{l}\text { contrast } \\
\text { enhancement } \quad \text { yes } \\
\end{array}$ & $\begin{array}{l}7.41( \pm 4.22) \\
9.50( \pm 7.78)\end{array}$ & 0.82 & & \\
\hline Tumor size & & 0.16 & & \\
\hline $\begin{array}{l}\text { Treatment groups } \\
\text { Sterotaxic biopsy } \\
\text { surgery }\end{array}$ & $\begin{array}{l}3.60( \pm 1.52) \\
7.95( \pm 3.95)\end{array}$ & $0.004^{*}$ & $0.006^{*}$ & $(2.67-33.2)$ \\
\hline $\begin{array}{l}\text { Total resection } \\
\text { Subtotal/partial res }\end{array}$ & $\begin{array}{l}8.50( \pm 2.69) \\
6.33( \pm 3.65)\end{array}$ & $0.03^{*}$ & $0.04^{*}$ & $(0.3-4.06)$ \\
\hline $\begin{array}{l}\text { Radiotherapy (-) } \\
\text { Radiotherapy (+) }\end{array}$ & $\begin{array}{l}5.85( \pm 4.45) \\
8.87( \pm 3.96)\end{array}$ & $0.04^{*}$ & $0.03^{*}$ & $(0.53-3.45)$ \\
\hline $\begin{array}{l}\text { Karnofsky score (discharge) } \\
\qquad \begin{array}{l}<70 \\
>70\end{array}\end{array}$ & $\begin{array}{l}4.56( \pm 2.70) \\
8.18( \pm 4.34)\end{array}$ & $0.005^{*}$ & $0.005^{*}$ & $(0.69-7.73)$ \\
\hline $\begin{array}{c}\text { Reoperation } \\
\text { yes } \\
\text { no }\end{array}$ & $\begin{array}{l}9.64( \pm 3.64) \\
6.86( \pm 4.32)\end{array}$ & $0.05^{*}$ & $0.05^{*}$ & $(0.39-2.00)$ \\
\hline
\end{tabular}

*statistically significant

While, total resection was successful on control CT and/or MRI in $28(56 \%)$ patients, subtotal resection in $16(32 \%)$ and partial resection in 1 patient. Five $(10 \%)$ patients underwent only stereotactic biopsy. The patients who had total resection survived longer period than the patients whom had subtotal removal (8.5 months and 6.3 months respectively, $\mathrm{p}=0.03$ ). The extent of resection was a significant independent prognostic factor also after multivariate analysis $(\mathrm{p}<0.05)$ (Figure 3$)$.
Radiotherapy: Four patients did not accept adjuvant therapy after stereotactic biopsy. They only followed up with medical supporting treatment. One patient accepted only radiotherapy after biopsy. Thirteen patients were followed up without any adjuvant therapy, 32 patients $(64 \%)$ received radiotherapy after resective surgery.

While 32 patients $(64 \%)$ received radiotherapy as adjuvant therapy after surgical resection, 13 patients 
Table II: Independent Prognostic Factors are Shown after Multivariate Analysis.

\begin{tabular}{|c|c|c|c|}
\hline & $\mathbf{P}$ value & \multicolumn{2}{|c|}{ Odds ratio } \\
\hline $\begin{array}{l}\text { Gender } \\
\text { female } \\
\text { male }\end{array}$ & $0.05^{*}$ & \multicolumn{2}{|c|}{$(1-0.05)$} \\
\hline Age & $0.05^{\star}$ & \multicolumn{2}{|c|}{$(1-0.46)$} \\
\hline $\begin{array}{l}\text { Treatment groups } \\
\text { sterotaxi } \\
\text { surgery }\end{array}$ & $0.004^{*}$ & 0.006 & $(2.67-33.2)$ \\
\hline $\begin{array}{l}\text { Total resection } \\
\text { Subtotal/partial res }\end{array}$ & $0.04^{*}$ & 0.52 & $(0.53-3.45)$ \\
\hline $\begin{array}{l}\text { Radiotherapy (-) } \\
\text { Radiotherapy (+) }\end{array}$ & $0.03^{*}$ & 0.08 & $(0.7-4.06)$ \\
\hline $\begin{array}{l}\text { Karnofsky score (discharge) } \\
\quad<70 \\
\quad>70\end{array}$ & $0.005^{*}$ & 0.17 & $(0.69-7.73)$ \\
\hline $\begin{array}{c}\text { Reoperation } \\
\text { yes } \\
\text { no }\end{array}$ & $0.05^{*}$ & 0.76 & $(0.39-2.00)$ \\
\hline
\end{tabular}

Table III: Radiological Characteristics.

\begin{tabular}{|l|r|r|}
\hline & $\mathbf{n}$ & $\%$ \\
\hline Localization & & \\
eloquent & 19 & 39.6 \\
noneloquent & 29 & 60.4 \\
\hline Contrast enhancement & & \\
yes & 46 & 95.8 \\
no & 2 & 4.2 \\
\hline Midline shift & & \\
yes & 33 & 68.8 \\
no & 15 & 31.2 \\
\hline Cyst & & \\
yes & 13 & 27.1 \\
no & 35 & 72.9 \\
\hline Edema & & \\
yes & 48 & 100 \\
no & 0 & 0 \\
\hline
\end{tabular}

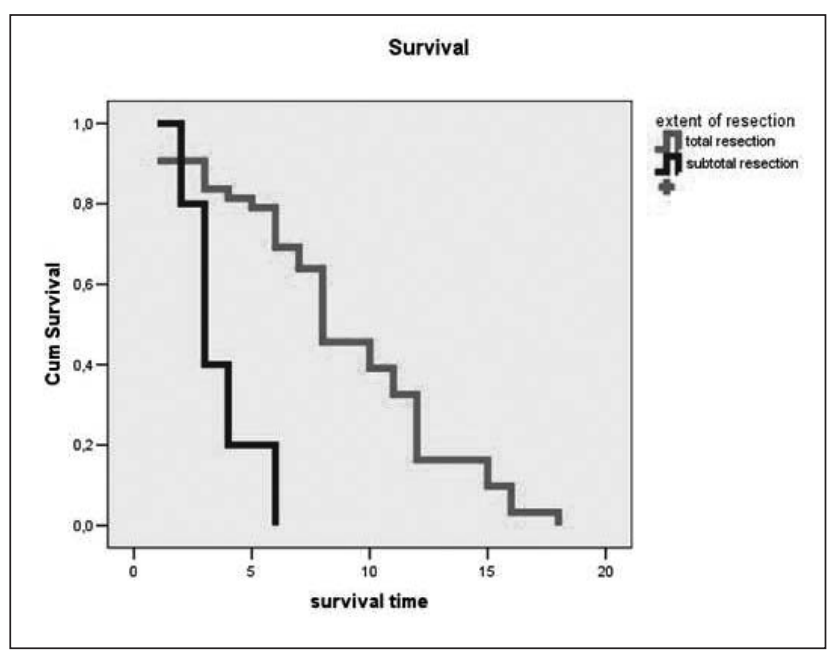

Figure 3: Overall survival curve according to extent of surgery.

refused the offered management. Survival times were significantly different between two groups based on the results of Log-Rank test and Multiple Cox regression analysis (8.87 months and 5.85 months respectively, $\mathrm{p}=0.03$ ). (Figure 4 ).

Reoperation: Tumor recurrences occurred at the site of the initial tumor in all patients. Eleven patients underwent at least 1 reoperation for 


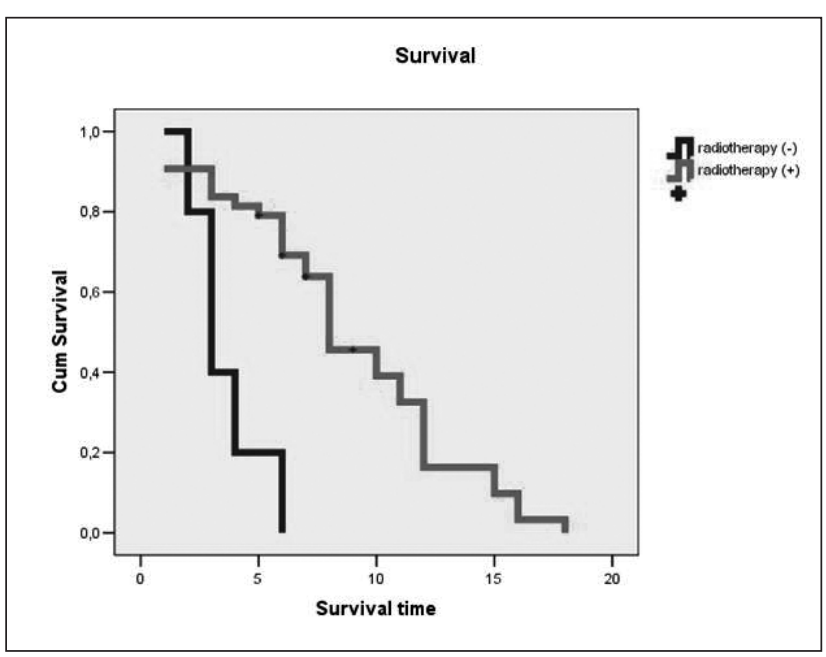

Figure 4: Effect of radiotherapy as an adjuvant therapy on survival curve.

recurrence or residual tumor. These patients were younger, and independent according to Karnofsky performance scale. The median survival time for the patients who underwent reoperation was significantly higher than for others, according to Log-Rank test $(\mathrm{p}<0.05)$. After multivariate analysis, its significance continued. Reoperation was independent prognostic factor according to Multiple Cox regression analysis $(\mathrm{p}<0.05)$ (Figure 5).

\section{DISCUSSION}

Glioblastoma is the most frequently diagnosed primary brain malign tumor in adults and invariably a fatal disease. Survival time is still approximately 1 year despite all the treatment modalities including surgical resection, radiotherapy and chemotherapy. The median survival time was 7.5 months in the

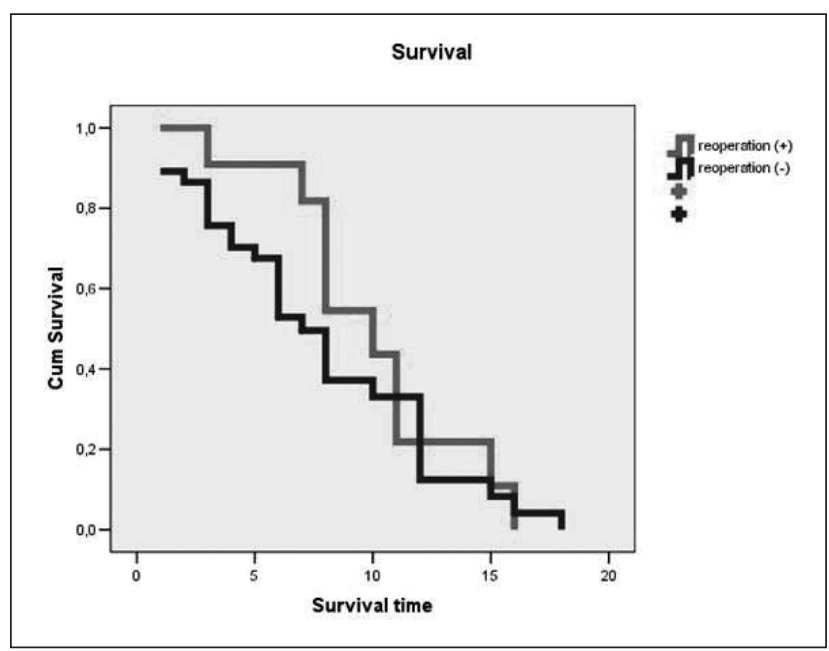

Figure 5: Effect of reoperation on survival curve. present study. We know that adjuvant therapy may extend the survival time. Some of our patients have been followed unless adjuvant therapy after initial surgical resection. This may explain the cause of short median survival time in the present study. Salcmann et al. reviewed the survival time and curve in malignant astrocytomas. He found those patients who reported after 1980 survived longer than those before 1980 with a same survival curve. Until recently, a 3 year life period for glioblastoma was indicated in $3 \%$ of patients and a 5 years life period it was indicated $0 \%$. Today there are documentations of patients surviving 10 years with GBM (27).

To date, a number of methods for predicting the prognostic subgroups of glioblastoma patients have been described. Furthermore age, Karnofsky performance score, tumor localization, tumor size, histopathologic subgroups, extend of resection, adjuvant therapy and reoperation are generally accepted parameters for prognosis.

Recent studies tend to evaluate molecular genetics or molecular biology rather than clinical or radiological subjects or prognostic factors. Results of studies of Annexin 7 expression, MIB labeling index and p 53 expressions are conflicting. The determination of the MIB I antibody against Ki67, which is a nuclear antigen may demonstrate the biologic behavior of the glioblastoma. Many reports have been published with the utilization of MIB I antibody as a prognostic parameter, but most of them had conflicting results especially for low-grade glioma.

Age and gender: In contemporary studies, the most important prognostic factor is age at the time of diagnosis $(5,6,13,16,17,20,21,23,25,33)$. Survival time is significantly longer in younger patients. Our findings supported this knowledge. Multivariate analysis also showed a clear correlation between increasing age and decreasing overall survival. Age associated comorbities, lower immunocompetence and possible resistance to adjuvant therapy in elderly patients may be a predisposing factor to adverse outcomes.

There is a male dominance in almost all incidence studies for glial malign tumors $(21,33)$. The present study is concordant with literature. Although authors usually do not emphasize gender as a prognostic factor, male gender was good prognostic 
factor in the present study. Furthermore, it was statistically significant after multivariate analysis. Gorlia et al. has reported that male patients had survived shorter than females in their series (10). However they thought that the higher multiple tumor incidences in male patients was a possible cause. There are few reports to determine male gender as bed prognosis in literature $(13,17)$. Reavey and Cartwell et al. have determined the female gender as a bad prognostic factor just like our series (23).

Duration of complaint: Duration of complaint was only 2 months in $1 / 3$ of patients in this study. More than half of patients had sign and symptoms due to increased intracranial pressure. Long duration of complaints and existence of epileptic seizures may indicate the secondary Glioblastoma originating from low-grade glial tumors. Many authors have found strong correlation between secondary glioblastoma and long survival time $(22,24,35)$. In this study almost all patients had primary glioblastoma and neither suffering time nor clinical symptoms showed correlation with survival time.

Preoperative and postoperative Karnofsky Performance Score: It has been reported that a higher performance score was strongly correlated with a longer survival time $(7,16,17,20,30)$. If the patient was dependent on others to provide daily life, survival time was shorter than others. In this study we found that postoperative Karnofsky Performance score had independently influence on survival. It is not surprising that the patients who were dependent tended to have occurrence of pulmonary embolisms and systemic problems like infections.

Location: There are several reports that localization of tumor may effect patient's survival time $(8,10,18,20,28,29)$. Extent of resections is generally more limited in tumors localized in eloquent brain regions. Lacroix et al. found that patients with Glioblastoma localized in eloquent regions had better prognosis but they could not define it as an independent factor in multivariate analyses (20). In the present study there was no association between the location of the tumor and the prognosis.

Radiologic findings: In addition to clinical parameters, many radiological variables have been evaluated as predicting prognosis in tumor patients. Recently, MR imaging has become standard in tumor patients. Degree of contrast enhancement may demonstrate the destruction of the blood-brain barrier. Furthermore, contrast enhancement is parallel with angiogenesis and neovascularisation. Hammoud et al. demonstrated that contrast enhancement of nidus may predict a worse prognosis (11). Contrast enhancement was seen in almost all patients. Thus we could not evaluate the prognostic value, statistically.

Mass effect and peritumoral edema were shown to be associated with a significantly shorter survival time in many studies (20). We did not perform any volumetric analysis to evaluate the effect of edema on survival time.

Extent of surgery: Extent of surgery has been associated with prognosis in many reports $(3,14,16,31)$. Mechanical cytoreduction is still the most effective therapy in malign astrocytomas. Cytoreduction with surgical resection also causes to increasing sensitivity to radiotherapy. The optimal extent of surgical resection depends on the tumor size and location. It is important to take tumor location into account when exploring an association between survival and surgical treatment. In many reports, involvement of eloquent brain was associated with shorter duration of survival $(20,28)$.

The extent of tumor resection has traditionally been classified into the categories of gross total resection, subtotal resection, partial resection and biopsy sampling. In recent studies, neuroimaging findings have been used to determine the extent of resection. Stereotactic biopsy sampling is associated with the shortest survival time in our study like many other reports $(10,16)$. Lacroix et al. have explored the prognostic significance of the extent of surgery based on neuroradiological quantification. They found a strong correlation in aggressive resection of $98 \%$ or more of tumor volume with a better prognosis (20).

Extent of resection not only depends on tumor location, but is also related to tumor volume, patient's neurological status, systemic condition and the experience of surgeon. Buckner et al also found that extent of resection was the most important factor for predicting survival (3). 
In the present study, although there was an association between longer survivals with extent of resection, it lost significance after multivariate analysis. We found that the median survival time (3.6 months) in patients undergoing only stereotactic sampling significantly differed from that of patients with resection (7.95 months).

Radiotherapy: Astrocytomas are more resistant to radiotherapy than other brain tumors in vitro studies. However unexceptionally adjuvant radiotherapy may add at least 5 months to survival time according to studies include large series $(6,25)$. The present study agrees with this knowledge. Salcmann has reviewed 1561 patients and has found that while patients survived only 4 months after surgery, patients who had undertaken adjuvant radiotherapy had survived 5 months longer (25). Furthermore, Brain Research Study Association has reported similar results (6). Wood et al. reported that if tumor volume increased during radiotherapy, the prognosis worsened (36). Chemotherapy may prolong survival time but in the present study unfortunately none of the patients received any additional therapies like chemotherapy.

Reoperation: The cause of death in the majority of patients with glioblastoma is primary neuronal disruption of the primary tumor. In the present study, recurrence occurred in all patients. We reoperated on only younger patients and patients with higher Karnofsky Scores. Nine months after reoperation, Barker reported that 15 percent of patients in first year and 31 percent of patients in the second year had undergone reoperation in Barker's series (2). Furthermore, one third of patients had a better performance score after reoperation. Reoperation was the significant prognostic factor according to our study. The median survival time (9.64 months) in patients undergoing at least one additional surgical resection was significantly longer from that of others (6.86 months) based on the results of multivariate analysis. Reoperation should be considered for especially for younger patients and those with better Karnofsky scores.

\section{CONCLUSION}

Regarding our results, young age, male gender, Karnofsky Performance Score between 70-100 at discharge, total surgical resection, using radiotherapy and reoperation were predictor for better prognosis. Especially, gender has not been mentioned as well known prognostic factor in previously reports. We found a strong correlation between male gender and better prognosis after Log rank and multiple Cox regression tests. Our findings also supported the well-known entity that radical surgery is important for longer survival. Radiotherapy also added a few months to mean survival time. There was a handicap for this study that nobody was taken chemotherapy during this study. Recently, chemotherapy became an important part of adjuvant therapy. Assessment of chemotherapy on the survival time in patients with glioblastoma, should be considered in new studies. Furthermore, we only evaluated the clinical, demographic and treatment modalities as prognostic factor, but we know that, molecular and genetic factors should be studied.

\section{REFERENCES}

1. Ammirati M, Galicich JH, Arbit E: Reoperation in the treatment of recurrent intracranial malignant gliomas. Neurosurgery 21:607-614, 1987

2. Barker FG 2nd, Chang SM, Gutin PH, Malec MK, McDermott MW, Prados MD, Wilson CB: Survival and functional status after resection of recurrent glioblastoma multiforme Neurosurgery. 42(4):709-720; discussion 720-723, 1998

3. Buckner JC: Factors influencing survival in high-grade gliomas. Semin Oncol 30(6 Suppl 19):10-14, 2003

4. Burger PC, Green SB: Patient age, histologic features, and length of survival in patients with glioblastoma multiforme. Cancer 59(9):1617-1625, 1987

5. Davis FG, Freels S, Grutsch J, Barlas S, Brem S: Survival rates in patients with primary malignant brain tumors stratified by patient age and tumor histological type: an analysis based on Surveillance, Epidemiology, and End Results (SEER) data, 1973-1991. J Neurosurg 88(1):1-10, 1998

6. Fazeny-Dorner B, Wenzel C, Veitl M, Piribauer M, Rossler K, Dieckmann K, Ungersbock K, Marosi C: Survival and prognostic factors of patients with unresectable glioblastoma multiforme. Anticancer Drugs 14(4):305-312, 2003

7. Gamburg ES, Regine WF, Patchell RA, Strottmann JM, Mohiuddin M, Young AB: The prognostic significance of midline shift at presentation on survival in patients with glioblastoma multiforme. Int J Radiat Oncol Biol Phys 48(5):1359-1362, 2000

8. Gehan EA, Walker MD: Prognostic factors for patients with brain tumors. Natl Cancer Inst Monogr 46:189-195, 1977

9. Gilbert H, Kagan AR, Cassidy F, Wagner J, Fuchs K, Fox D, Macri I, Gilbert D, Rao A, Nussbaum H, Forsythe A, Eder J, Latino F, Youleles L, Chan P, Hintz BL: Glioblastoma multiforme is not a uniform disease! Cancer Clin Trials 4(1):87-89, 1981

10. Gorlia T, van den Bent MJ, Hegi ME, Mirimanoff RO, Weller M, Cairncross JG, Eisenhauer E, Belanger K, Brandes AA, Allgeier A, Lacombe D, Stupp R: Nomograms for predicting survival of patients with newly diagnosed glioblastoma: 
Prognostic factor analysis of EORTC and NCIC trial 2698122981/CE.3. Lancet Oncol 9(1):29-38, 2008

11. Hammoud MA, Sawaya R, Shi W, Thall PF, Leeds NE: Prognostic significance of preoperative MRI scans in glioblastoma multiforme. J Neurooncol 27(1):65-73, 1996

12. Harsh GR 4th, Levin VA, Gutin PH, Seager M, Silver P, Wilson $\mathrm{CB}$ : Reoperation for recurrent glioblastoma and anaplastic astrocytoma. Neurosurgery 21(5):615-621, 1987

13. Hirano H, Asakura T, Yokoyama S, Kadota K, Kasamo S, Okahara K, Hirakawa W, Niiro M, Nakamura K, Nakayama M, Yamasaki I: The prognostic factors in astrocytic tumors: Analysis by the Kaplan-Meier method and the Weibull loglinear model [Article in Japanese]. No Shinkei Geka 24(9):80915, 1996

14. Hoshino T: A commentary on the biology and growth kinetics of low-grade and high-grade gliomas. J Neurosurg. 61(5):895900, 1984

15. Hung KS, Howng SL: Prognostic significance of annexin VII expression in glioblastomas multiforme in humans. J Neurosurg 99(5):886-92, 2003

16. Jeremic B, Milicic B, Grujicic D, Dagovic A, Aleksandrovic J: Multivariate analysis of clinical prognostic factors in patients with glioblastoma multiforme treated with a combined modality approach. J Cancer Res Clin Oncol 129(8):477-84, 2003

17. Jeremic B, Milicic B, Grujicic D, Dagovic A, Aleksandrovic J, Nikolic N: Clinical prognostic factors in patients with malignant glioma treated with combined modality approach. Am J Clin Oncol 27(2):195-204, 2004

18. Kathleen R. Lamborn, Susan M. Chang, Michael D. Prados: Prognostic factors for survival of patients with glioblastoma: Recursive partitioning analysis. Neuro-Oncology 6(3):227235,2004

19. Kim TS, Halliday AL, Hedley-Whyte ET, Convery K: Correlates of survival and the Daumas-Duport grading system for astrocytomas. J Neurosurg 74(1):27-37, 1991

20. Lacroix M, Abi-Said D, Fourney DR, Gokaslan ZL, Shi W, DeMonte F, Lang FF, McCutcheon IE, Hassenbusch SJ, Holland E, Hess K, Michael C, Miller D Sawaya RJ: A multivariate analysis of 416 patients with glioblastoma multiforme: prognosis, extent of resection, and survival. Neurosurg 95(2):190-198, 2001

21. Mao Y, Desmeules M, Semenciw RM, Hill G, Gaudette L, Wigle DT: Increasing brain cancer rates in Canada. CMAJ 145(12):1583-91, 1991

22. McKeran RO et Thomas DGT: The Clinical Studies of Glioma. In: Thomas DGT et Graham DI (eds), Brain tumors scientific Basis, Clinical Investigation, and Current Therapy. London: Butterworth: 194-230

23. Reavey-Cantwell JF, Haroun RI, Zahurak M, Clatterbuck RE, Parker RJ, Mehta R, Fruehauf JP. Brem H: The prognostic value of tumor markers in patients with glioblastoma multiforme: analysis of 32 patients and review of the literature. J Neurooncol 55(3):195-204, 2001
24. Roth JG, Elvidge AR: Glioblastoma multiforme: A clinical survey. J Neurosurg. 17:736-750, 1960

25. Salcman M: Survival in glioblastoma: Historical perspective. Neurosurgery. 7(5):435-439, 1980

26. Salcman M: Epidemiology and factors affecting survival. In Apuzzo MLJ (ed.) Malignant cerebral Glioma. Park Ridge, IL; American Association Neurological Surgeons 1980: 95-109

27. Salvati M, Cervoni L, Artico M, Caruso R, Gagliardi FM: Longterm survival in patients with supratentorial glioblastoma. J Neurooncol 36(1):61-64,1998

28. Sawaya R, Hammoud M, Schoppa D, Hess KR, Wu SZ, Shi WM, Wildrick DM: Neurosurgical outcomes in a modern series of 400 craniotomies for treatment of parenchymal tumors. Neurosurgery 42(5):1044-1055; discussion 1055-1056. 1998

29. Scott JN, Rewcastle NB, Brasher PM, Fulton D, Hagen NA, MacKinnon JA, Sutherland G, Cairncross JG, Forsyth P: Longterm glioblastoma multiforme survivors: a population-based study. Can J Neurol Sci 25(3):197-201, 1998

30. Scott JN, Rewcastle NB, Brasher PM, Fulton D, MacKinnon JA, Hamilton M, Cairncross JG, Forsyth P: Which glioblastoma multiforme patient will become a long-term survivor? A population-based study. Ann Neurol 46(2):183-188, 1999

31. Shinojima N, Kochi M, Hamada J, Nakamura H, Yano S, Makino K, Tsuiki H, Tada K, Kuratsu J, Ishimaru Y, Ushio Y: The influence of sex and the presence of giant cells on postoperative long-term survival in adult patients with supratentorial glioblastoma multiforme. J Neurosurg 101(2):219-226, 2004

32. Tortosa A, Vinolas N, Villa S, Verger E, Gil JM, Brell M, Caral L, Pujol T, Acebes JJ, Ribalta T, Ferrer I, Graus F: Prognostic implication of clinical, radiologic, and pathologic features in patients with anaplastic gliomas. Cancer 97(4):1063-1071, 2003

33. Trouillas P, Menaud G, De The G, Aimard G, Devic M: Epidemiological study of primary tumors of the neuraxis in the Rhone-Alps region. Quantitative data on the etiology and geographical distribution of 1670 tumors], Rev Neurol 131(10):691-708. 1975

34. Walker MD, Alexander E Jr, Hunt WE, MacCarty CS, Mahaley MS Jr, Mealey J Jr, Norrell HA, Owens G, Ransohoff J, Wilson $\mathrm{CB}$, Gehan EA, Strike TA: Evaluation of BCNU and/or radiotherapy in the treatment of anaplastic gliomas. A cooperative clinical trial. J Neurosurg. 49(3):333-343, 1978

35. Walker MD, Green SB, Byar DP, Alexander E Jr, Batzdorf U, Brooks WH, Hunt WE, MacCarty CS, Mahaley MS Jr, Mealey J Jr, Owens G, Ransohoff J 2nd, Robertson JT, Shapiro WR, Smith KR Jr, Wilson CB, Strike TA: Randomized comparisons of radiotherapy and nitrosoureas for the treatment of malignant glioma after surgery. N Engl J Med. 303(23):13231329, 1980

36. Wood JR, Green SB, Shapiro WR.: The prognostic importance of tumor size in malignant gliomas: a computed tomographic scan study by the Brain Tumor Cooperative Group. J Clin Oncol 6(2):338-343, 1988 